\title{
State of Exception as Economic Policy: A Socio-Legal Analysis of the Puerto Rican Colonial Case
}

J OSÉ ATILES-OSORIA*

\begin{abstract}
Atiles-Osoria, J., 2018. State of Exception as Economic Policy: A Socio-Legal Analysis of the Puerto Rican Colonial Case. Oñati Socio-legal Series [online], 8 (6), 819-844. Received: 29-11-2017; Accepted: 18-05-2018. Available from: https://doi.org/10.35295/osls.iisl/0000-0000-0000-0975
\end{abstract}

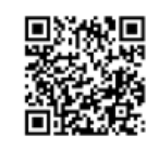

\begin{abstract}
This article argues that the Puerto Rican colonial-economic, political and legal development has been based on the state of exception. By analyzing the Puerto Rican constitutional history and the sociopolitical events taking place after the 1980's it shows that in PR, a double exceptionality operates: a colonial state of exception, which refers to the US's uses of this paradigm as a colonial domination technique; and an internal state of exception, which refers to the uses of this paradigm by the Puerto Rican government as a dispositive to tackle economic and financial crises. This innovative approach portrays a more complex understanding of the state of exception, one that better portrays the intertwined relations between colonialism, economy and law.
\end{abstract}

\section{Key words}

State of exception; colonialism; economic and financial crisis; Puerto Rico; depoliticization

\section{Resumen}

Este artículo muestra que el estado de excepción es la base del desarrollo económico, jurídico, político y colonial de Puerto Rico (en adelante, PR). A partir del análisis de la historia constitucional de PR y los eventos sociopolíticos que han ocurrido a partir de la década del 1980 muestra que en PR opera una doble excepcionalidad: el estado de excepción colonial, o el uso de este paradigma por parte de EEUU como técnica de dominación colonial; y, el estado de excepción interno, o el uso de este paradigma por parte de los gobiernos locales para atender las crisis económicas y financieras. Esta aproximación innovadora representa una comprensión más compleja y rica del estado de excepción, ya que nos permite mostrar la interconexión entre colonialismo, economía y derecho.

\footnotetext{
I will like to thank the participants of the Workshop: State of Exception, Law and Economics: A Socio-legal approach to the economy of exception in an era of crisis, hosted by the IISJ in June 2016, for their comments and recommendations. Additionally, I will like to thank David Whyte for his support and contributions to this paper. Finally, I am thankful for the comments and many revisions made by the reviewers of this paper.

* José Atiles-Osoria is a Postdoctoral Researcher at the Centre for Social Studies of the University of Coimbra and Adjunct professor of Philosophy at the University of Puerto Rico, Mayagüez. Postal address: Colégio de S. Jerónimo, Apartado 308, 3000-995 Coimbra, Portugal. Email: jose.atiles@upr.edu. ORCID: https://orcid.org/0000-0001-5711-7101
}

\section{(cc) EY-NC-ND}

Oñati International Institute for the Sociology of Law Antigua Universidad s/n - Apdo.28 20560 Oñati - Gipuzkoa - Spain

Tel. (+34) 943783064 


\section{Palabras claves}

Estado de excepción; colonialismo; crisis económicas y financieras; Puerto Rico; despolitización 


\section{Table of contents / Índice}

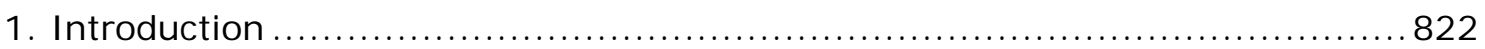

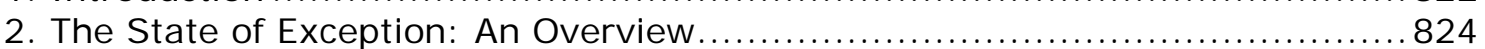

3. US Colonial State of Exception and the Puerto Rican Economy.................... 827

4. Colonial Neoliberalism and Internal State of Exception......................... 831

5. The Internal State of Exception and the Reaffirmation of US Colonial State of

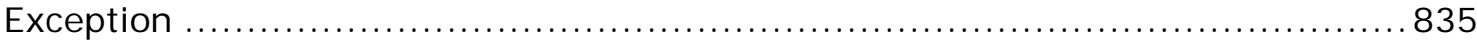

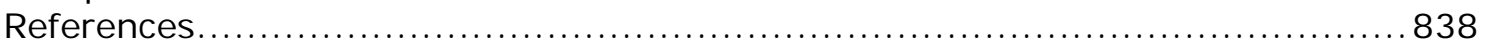

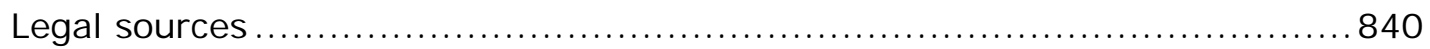

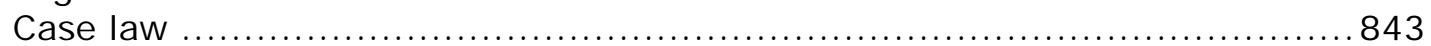


The use of emergency measure as instruments of economic regulation and class subjugation must be understood against some important and related contextual backdrops: the intimate relationship that exists between capitalism and imperialism, the function of economic governance as an apparatus of security, and the susceptibility of capitalist economies to periodic 'crisis' (...). The state of emergency has it colonial origins. The colonial account of emergency cannot be written without reference to capitalist expansion. (Reynolds 2012, pp. 88-89)

\section{I ntroduction}

For the last four years, the international press has been discussing and analyzing the Puerto Rican economic and financial crisis. Titles such as: Puerto Rico: Greece in the Caribbean (The Economist 2013), The tragedy of Puerto Rico: America's very own Greece (Salmon 2015), Puerto Rico could become a humanitarian crisis (Rosenfeld 2015), Puerto Rico's Fiscal Crisis has been Brewing for 75 Years (J offe 2016), Greek Tragedy Redux? Puerto Rico Embraces Risky Austerity Plan (Kaske 2018) have portrayed a scenario in which the economic and financial situation in Puerto Rico (PR), a US colony or unincorporated territory, is on the edge of a serious political and humanitarian crisis. Those portrayals became real on May $1^{\text {st }}, 2016$, when the local government and its Government Development Bank defaulted on a $\$ 442$ million bond payment (Eyermann 2016). A second default came in June $1^{\text {st }}, 2016$, when the government could not pay a $\$ 2,000$ million loan (Marans 2016). These defaults came after at least a two-decade long economic recession, and a decade long economic and financial crisis.

After the default, the US colonial government took direct actions to address the Puerto Rican crisis by legislating the Puerto Rico Oversight, Management, and Economic Stability Act or PROMESA (S. 2328, 2015-2016), which redefines the economic, political and legal structures of PR, designs the mechanisms to impose a series of austerity measures, and includes the imposition of a Financial Oversight and Management Board to control Puerto Rican finances for the next years. In tandem with this, the US Supreme Court ruled on two cases that, to a certain extent, redefined the economic and colonial condition of PR: Commonwealth of Puerto Rico v Sánchez Valle et al. (15-108) (2016), and Commonwealth of Puerto Rico et al. v Franklin California Tax-Free Trust et al. (15-233) (2016). Along with these cases, on May 2017, the Financial Oversight and Management Board activated Chapter III of PROMESA, which allowed the Puerto Rican government to restructure its $\$ 122$ billion debt by going into bankruptcy. ${ }^{1}$ Nevertheless, these episodes were not the last in the Puerto Rican crisis saga; even after the default, the US legislation and imposition of PROMESA, and the beginning of the bankruptcy case, hurricanes Irma and Maria struck PR in September 2017, leaving the Island's infrastructure, economy and environment practically destroyed. ${ }^{2}$

This paper aims to show that the economic, political and legal policies implemented by the US government and by the local government of PR to address the economic and financial crisis have been based on the state of exception. However, in PR, a double exceptionality operates: a colonial state of exception, which refers to the US's uses of this paradigm as a colonial domination technique; and an internal state of exception, which refers to the uses of this paradigm by the Puerto Rican government as a dispositive to tackle economic and financial crises (Atiles 2016). This double exceptionality, its operability and effects, is precisely what this paper aims to elucidate.

The traditional understandings of the state of exception refer to the suspension of the state law to manage periods of political violence, economic crisis or natural

\footnotetext{
${ }^{1}$ The bankruptcy case is being held in the US District Court for the District of PR (the federal court). The case is Financial Oversight and Management Board for Puerto Rico, 17-cv-01578, U.S. District Court.

${ }^{2}$ Given that the research that led to this paper was conducted before Hurricane Maria, I am not including the aftermath of the hurricane in the analysis. For an analysis of that post-Maria period, see Atiles (forthcoming 2018).
} 
disaster. That is, periods in which the law cannot act in its normal way (Agamben 2005). All of these circumstances have required governments to take on special powers that allow them to effectively respond to periods of crisis (avoiding political debates, and therefore, democracy). In short, the implementation of the state of exception takes place when the Sovereign considers the suspension of the rule of law as necessary (Schmitt 2005). Agamben (2005) has shown that the state of exception is not a special law, but rather, it is a juridical-political dispositive implemented by contemporary liberal democracies to create a situation in which the rule of law and the constitution, even though present, are suspended. The space of anomie constituted by the state of exception does not entail the abolition of the constitution and the rule of law, but rather, it consists on the suspension of the law to apply the violence of law. As a result of the "insecurity, economic crises, and natural disaster", the state of exception has become the norm.

My understanding of the state of exception is rather different to the work of Agamben (2005). That is, while Agamben (2005) is looking at the state of exception from above, from the experience of the global north, my understanding of the state of exception is informed by the experiences of the global south, the colonies and the oppressed. As Walter Benjamin reminded us in his Thesis VIII: "the tradition of the oppressed teaches us that the 'state of emergency' in which we live is not the exception but the rule". I have shown elsewhere that the colonial state of exception is not a suspension of state law, but rather the constitutive dispositive of colonial domination (Atiles 2016). That is, the colonial state of exception is not the suspension of the law, but rather the way in which empires legitimate colonial domination. The colonial state of exception operates in an onto-political way, meaning that the colonial government imposes and uses exceptionality as a way to define the colonial sociopolitical reality, deciding which laws apply to the colonial territory, imposing different legal systems, and creating legal subjects. In sum, the colonial state of exception is the way in which inclusive exclusion or exclusive inclusion take place in colonial territories.

Alongside the definition of the colonial state of exception, I have identified that the Puerto Rican local government has used the state of exception as a dispositive to address economic crises, social unrest and natural disasters (Atiles 2016). Evidently, the colonized Puerto Rican government has the sovereignty to declare the suspension of the local law, but not the suspension of the colonial state of exception. Therefore, my argument is that, in PR, the development of an internal state of exception can be identified. The internal state of exception operates in the same way as the state of exception as studied by Agamben (2005) in the global north. That is, the internal state of exception suspends the local law to address any given crisis or necessity. However, it is important to bear in mind that this suspension of local law, which can become permanent, is possible on the local level only because the US government (that is, the colonial state of exception) allows it.

With this in mind, I would like to move my analysis to the economic dimension of the state of exception. To do so, in the colonial territory of PR, it is necessary to look at both the colonial state of exception and the internal state of exception, since, while the colonial state of exception was implemented to create the legal, political and economic super-structure, the internal state of exception (which can be seen as the infrastructure) has been used to address the economic and financial crisis since its beginnings in 2006. To summarize, the US government has used the colonial state of exception to create the economic and legal structure of PR, while the local government has used the internal state of exception to deal with the crisis.

In a way, the internal state of exception is similar to what Schmitt (2006) has called the economic and financial state of emergency, and what other authors have analyzed as the connection between the state of exception, the economy and neoliberalism. As example Ong (2006) and Reynolds (2012) have shown that a common practice in current neoliberal politics consists of using the state of exception 
as a strategy to deal with economic crises. That is, neoliberalism ${ }^{3}$ has employed the state of exception as a legal and political dispositive to address economic crises. The Puerto Rican case is consistent with the global north and south experiences with neoliberalism and its uses of the state of exception. However, in the Puerto Rican colonial case, as shown earlier, the uses of the economic state of exception take place in the context of a colonial state of exception (Atiles 2016), which implies a more complex dimension of the relation between the state of exception and economy. Thus, this paper aims to show how the interconnection between the state of exception, colonialism, and the economy has been at the core of colonial politics in PR.

Tangled up with the normalization of the crisis and of exceptionality, solutions and alternatives to the Puerto Rican crisis have been those typical of neoliberalism. Some examples of the alternatives and solutions are: structural adjustment; budgetary cuts; austerity measures; privatization of public goods, services and public corporations; and the development of economic discourses that state that the debt has to be paid before any other aspect of public life. Following Brown (2015), I argue that Puerto Rican contemporary politics have suffered the processes of economization and depoliticization that neoliberalism entails. These processes of depoliticization and economization of Puerto Rican politics - although they existed prior to neoliberalism, given that these processes are part of the capitalist-colonial structure imposed by the US since 1898- have been central in the neoliberal-hegemonic interpretation of the current economic crisis. This explains why the analyses and interpretations of the current crisis have silenced the colonial history of economic development, the legal and political history of colonialism and colonialism itself. Consequently, the solution to the crisis seems to be more colonialism, and thus, the suspension of the few constitutional and democratic guarantees that PR has achieved. That is, in the colonized Puerto Rican juridical-political and economic understanding, and in the US hegemonic-neoliberal-colonialist view, the solutions to the economic crisis are the intensification of the measures that generated the current crisis, hence, the colonial state of exception.

This paper will be divided into four sections: (2) an overview of the paradigm of the state of exception; (3) an addressal of the legal, political and economic configuration of the US colonial state of exception in PR; (4) an analysis of the development of colonial neoliberalism and of the internal state of exception; and (5) an exposition of the reaffirmation of the US colonial state of exception in PR in the post 2016 era. The previous sections will show that the state of exception has always been linked to the very existence of colonial domination, and that the alternatives to solving the economic and financial crisis start with decolonizing and repoliticizing Puerto Rican politics.

\section{The State of Exception: An Overview}

The state of exception has become a key concept for the understanding of the legal and sociopolitical transformation contemporary democracies are undergoing. Despite the importance of this analysis, I have identified three important gaps: 1) the relationship between colonialism and the state of exception has been neglected; 2 ) the connection between the state of exception and the economy, although it has been studied, lacks a proper theory; 3) with few exceptions, there are no studies that portray the connection between the state of exception, colonialism, and the economy. In this sense, this section develops these three gaps, and proposes a general theoretical framework that would help develop the analysis of the Puerto Rican case.

\footnotetext{
3 For the purposes of this paper, I will be using Brown's (2015) depiction of neoliberalism. For Brown; "neoliberalism is a distinctive mode of reason, of the production of subjects, a "conduct of conduct" and scheme of valuation, it names a historically specific economic and political reaction against Keynesianism and democratic socialism, as well as a more generalized practice of "economizing" spheres and activities heretofore governed by the other tables of values" (Brown 2015, p. 21).
} 
Agamben (2005) proposes the paradigm of the state of exception to exemplify the exercise of sovereign power in the contemporary era. In his philosophical and genealogical analysis, Agamben (2005) shows that the history of the state of exception is the history of its progressive separation from periods of war, to become the administrative paradigm of contemporary democracies. Agamben $(1998,2005)$ argues that from WWI onwards, the state of exception has become the norm, leaving aside its provisional and temporal character. For Agamben (2005), this separation from its earliest definition triggers the technification of governmental power and the depolitizaction of politics. In this way, the state of exception has become the administrative dispositive of the post 9/11 era (Butler 2004) and of neoliberalism.

The implicit argument in Agamben's work is that the global north has lived in a permanent state of exception since WWI, given the crisis generated by capitalism. To be sure, economic crises, political violence, and natural disasters are (in)direct products of capitalism, since it operates through the commodification of every aspect of life (including life itself), and the massive exclusion of socio-political sectors and plunder of natural recourses. In this sense, the neoliberal technification of politics is the latest version of the modern-liberal aspiration of configuring a society free of conflict, in which decisions are based, not on democratic debates, but on effectiveness, efficiency and productivity criteria. Thus, the state of exception has become the governmental technology or dispositive that facilitated the neoliberal legal and political transformations of the state and society. As a result, the neoliberal implementation of the state of exception in contemporary democracies is changing the definitions of citizenship and sociopolitical inclusion/exclusion (Ong 2006).

To exemplify these processes of depoliticization, Agamben $(1998,2005)$ proposes a bidimensional interpretation. On the one hand, Agamben considers the politicophilosophical and ontological dimensions of the state of exception. This tradition is studied through a genealogy of power in Western democracies. On the other hand, Agamben (2005) engages in the analysis of the legal history or the jurisprudence of the state of exception. This tradition is explored through a philosophical archaeology of the political and constitutional history of the state of exception. In this context, the analysis of the state of exception gravitates around the codification of the state of emergency, siege and exception in the global north.

Regarding the first tradition, Agamben (1998) considers that the ontological configuration of the state of exception is defined by the paradox of sovereignty: to be outside the law and at the same time defining the applicability of the law. The paradox of sovereignty is fundamental to understanding the political power that define the constitutive dimension of anomie. Agamben argues:

In truth, the state of exception is neither external nor internal to the juridical order, and the problem of defining it concerns precisely a threshold or zone of indifference, where inside and outside do not exclude each other but rather blur with each other. The suspension of the norm does not mean its abolition, and the zone of anomie that it establishes is not (or at least claims no to be) unrelated to the juridical order. (Agamben 2005, p. 23)

The best example of the processes of defining a political entity through its exclusion can be found in the colonial context of PR and its legal tautological definition: PR belongs to the US, but at the same time, it is not part of it (Burnett 2005, Venator 2006). This legal definition has enabled the exercise of the US's colonial power in PR through inclusive exclusion. The processes of inclusive exclusion imply the superposition of sovereign power over any form-of-life and the construction of spaces of anomie where the law does not apply in its regular manner. Hence, the state of exception enforces legal violence in the form of force-of-taw. Agamben (1998, 169) defines force-of- as "being in force without significance". This has entailed manifestations of power, such as: the naked life, the Camp, and the economization of life. In this paper, I am going to focus exclusively on the economization of life and its implications for colonial contexts. 
Regarding the second tradition, Agamben (2005) has shown that this concept has been used in various historical contexts, such as the Roman Empire, the French Revolution and the Nazi concentration camps. Nowadays, emergency powers, as part of a war on terror, have been invoked to support US global hegemony (Butler 2004). However, Agamben's (2005) account falls short when it comes to addressing the implementation of the state of exception in colonial contexts. Contrary to Agamben, Mbembe (2003) has shown that the colonial state has used the state of exception as a dispositive of colonial rule. For Mbembe (2003), it was the colony, and not the Camp, that was the space of anomie that inaugurated the implementation of sovereignty as the power to decide who lives and who dies. Thus, Mbembe (2003) shows that the colony is the place par excellence for the existence of the state of exception. Similarly, Morton (2013) identifies that the true manifestation of the permanent state of exception can be found in colonial contexts. Put simply, in colonies, the state of exception is the norm. As shown earlier, this paper aims to show how the US implemented a state of exception in PR as a dispositive for the administration of the colonial territory, and how that colonial state of exception created the conditions for the capitalist and imperialist domination of PR.

Regarding the relation between the state of exception and economy, while it is true that Agamben (2005) suggests that the state of exception has been used as a political and legal strategy to tackle periods of economic crisis, he fails to delve into the analysis of this dimension of the state of exception. As an example, in Homo Sacer, Agamben (1998) pays little attention to the uses of the state of exception to deal with economic crises. Even though Agamben (2008) dedicated The Kingdom and the Glory to the analysis of the history of the concept of oikonomia and its intertwined relations with the concept of governmentality in Western democracies, he did not pay attention to the uses of the state of exception in economic crises. It is only in State of Exception (Agamben 2005) that some references to the uses of this dispositive in the normalization of economic crises can be found. However, those references only deal with: experiences with the regulation of inflation in France and Germany; the uses of exceptional laws and policies in the context of the US's Great Depression; among other global north experiences. Hence, a proper theory of the uses of the state of exception as economic development policy and crises management is lacking.

I have identified three important exceptions of this trend. Firstly, Ong (2006) has shown that neoliberalism works through exceptional laws to facilitate the control and "optimization" of economic development. In her analysis of neoliberal uses of the state of exception as a technology of government in non-western societies, Ong exposes how the logic of crisis and exceptional measures has become the norm. Secondly, Whyte (2010) has analyzed the correlation between the state of exception and the economy in the context of the Iraq invasion. In his analysis, Whyte (2010) has shown the uses of the state of exception to facilitate the establishment of a capitalist economy based on foreign corporations. Thirdly, Reynolds (2012) argues that the development of the state of exception in the colonies cannot be understood without its direct relation to the capitalist economy. As Reynolds reminds us, "Emergency intervention in the economy by the Western state has long been common in contexts of war or insurrection, and in contexts of race and class domination in the colonies" (Reynolds 2012, p. 97).

That is, the uses of the state of exception as a dispositive to manage economic and financial crises have become the norm in the global north after the meltdown of 2007. This government technique has been implemented by governments and by international organizations, such as FMI and the Troika in Greece, Ireland, Portugal, Italy and Spain. The arguments heralded by the crisis managers have been the same; given the economic and financial crises, the debt and the deficit, the governments have to implement austerity measures and budgetary cuts to save the economy and the state. However, every time such policies are implemented under the legitimation 
of the state of exception, inequality increases, appropriation, theft and corruption become normalized, and the violence of austerity ${ }^{4}$ generalized.

The US imposition of PROMESA and the Control Board in PR is concomitant with these international practices and techniques of governmentality. But also, at the local level, this has been the case of the implementation of the internal state of exception by the local government as a dispositive to protect colonial-capitalism in PR. In what follows, I am going to expose the way in which the colonial state of exception and the internal state of exception became the form-of-government in the colonial context of PR.

\section{US Colonial State of Exception and the Puerto Rican Economy}

The Puerto Rican government, the legal definition of Puerto Rican identity and PR's relation with the US have been based on the colonial state of exception. In order to show the design and imposition of the colonial state of exception in PR, and its uses as economic policy, in what follows, I will briefly outline Puerto Rican colonial, legal, political and economic history. ${ }^{5}$

As a result of the Cuban-Spanish-American War, the US invaded PR on the 25th of July in 1898, and after the end of the hostilities between both imperial powers and the signing of the Treaty of Paris, PR became a US colony ${ }^{6}$ (Ayala and Bernabe 2011). Later, PR became a domain of the US Congress under the Territorial Clause of the US. ${ }^{7}$ Consequently, three exceptional laws were legislated, which sought to regulate the colonial juridical-political and economic relationship. ${ }^{8}$

The first of these exceptional laws was the Foraker Act (1900). This law ended two years of military rule ${ }^{9}$ and led to the establishment of a civilian government (largely administered by the military). The Foraker Act (1900) defined three key aspects of colonial life: the political system; the economic structures; and US-PR relations. Concerning the economic structures, articles 2, 3, 4, 5, 9, 11, 12 and 13 deal with tax collection, the definition of market economy, and the establishment of the monetary system (Dietz 1986).

In tandem with the Foraker Act, from 1898 to 1900, the US imposed a series of economic and monetary measures that lead to the devaluation of the currency and real estates, and the impoverishment of the local pro-Spanish hacendados (Ayala and Bernabe 2011). These policies also facilitated massive land purchase (hence, the dispossession of local peasants) by US corporations (Irizarry, 2011). US corporation control of the land was so massive that in 1900, the US Congress passed the 500 Acres Law (see Cintrón Aguilú 2014), which aimed to limit land concentration to few hands. Along with the impoverishment of the local hacendados, from 1898 to 1930, the US enforced a radical transformation of agricultural production (Dietz 1986). This transformation consisted of changing the coffee-based and self-sustaining agricultural economy to a sugarcane monoculture.

Simultaneous to this economic transformation, from 1900 to 1922, in a series of cases called the Insular Cases, the US Supreme Court ruled what would become the legal definition of PR (López 1999, Rivera 2001, Venator 2006). That is, the rulings issued in the Insular Cases provided the legal framework for the US's colonial control

\footnotetext{
${ }^{4}$ Here, I follow Cooper and Whyte's (2017) analysis of the violence of austerity.

${ }^{5}$ For the purposes of this article, I am going to expose a brief summary of the key moments in the history of US colonialism in PR. For a detailed analysis, see Atiles (2016).

6 Treaty in which Spain transferred sovereignty over PR, Guam and the Philippines to the US.

${ }^{7}$ US Constitution Article IV-3, Clause 2: "The Congress shall have Power to dispose of and make all needful Rules and Regulations respecting the Territory or other Property belonging to the United States; and nothing in this Constitution shall be so construed as to Prejudice any Claims of the United States, or of any particular State".

${ }^{8}$ It is important to note that the Insular Cases and the exceptional laws imposed on PR were based on and addressed economic controversies.

${ }^{9}$ Estades (1999) has shown that in the first two years of the US colonial administration in PR, the Island was ruled by the military. Likewise, Rivera Ramos (2001) argues that these first two years, PR was under the Martial Law. For an in-depth analysis of this period, also see Atiles (2016).
} 
of PR. The juridical-political designation of PR and other unincorporated territories as spaces of anomie, a particular type of state of exception, was imposed through the designation of these territories as "belonging to, but not being part of the US". This implies that these territories and colonial subjects are in an area of juridical-political indistinctness which, according to Agamben (2005), sometimes exists within, and sometimes without, the constitutional guarantees and procedures of the rule of law.

Additionally, the Insular Cases have established categories that define and assign a particular identity to Puerto Ricans, an identity that is different from that assigned to US citizens: "PR and Puerto Ricans are foreign in a domestic sense" (Burnett 2005). This has determined the legal truth about the Island, a truth that seeks to legitimize a geopolitical zone that has been identified as an unincorporated territory (Rivera 2011). Just as this anomic space was created, a different juridical category was constituted for Puerto Rican subjects who, though nominally are US citizens, have not been granted all of the constitutional guarantees, rights and privileges of US citizenship. In this sense, Jiménez (forthcoming 2018), in her excellent analysis of the Insular Cases, and particularly in her depiction of Downes v Bidwell (1901), has shown how the US Supreme Court developed the racial dimension of the colonial state of exception in PR. Jimenez's (forthcoming 2018) point further proves that the US has implemented the colonial state of exception as a dispositive of normalization and administration of PR's socio-legal and political reality.

Continuing with the historical analysis of the US colonial state of exception in PR, in 1917, the second organic law, commonly known as the Jones Act, came into force. This law of exception partially replaced the Foraker Act and extended US citizenship to Puerto Ricans. The citizenship granted by the Jones Act, while recognizing certain basic civil rights and guarantees, also deprived Puerto Ricans living in PR of benefiting from some of the inherent political rights and constitutional guarantees of US citizenship. Some of the rights and guarantees Puerto Ricans were excluded from: having representation in the US Congress, participation in presidential elections, accessing certain social services, among others.

Lately, in 1920, the Cabotage Laws were imposed on PR. Cabotage Laws regulate commerce and impose the requirement that the shipping and trade of products imported to and exported from PR must take place on ships made in the US, or at least registered in the US. That is, the Cabotage Laws, which are still in force in PR, guarantee colonial-economic domination through the limitation of trade.

As a result of the Great Depression of the 1930s, the practices of most institutions and political parties underwent radical transformations (Ayala and Bernabe 2011). This transformation, in turn, was experienced in the US with the implementation of the New Deal and a series of exceptional measures aimed at reactivating the economy. The New Deal and the social reforms advanced by the Roosevelt administration were extended to PR under various economic measures and plans: ${ }^{10}$ (1) in 1933, the Puerto Rico Emergency Relief Administration was established as a branch of the Federal Emergency Relief Administration; (2) the Roosevelt administration proposed the reorganization of the US sugar industry and its policies in territories through the Sugar Act of 1934; (3) in 1935, the Plan Chardón was developed, which sought to create a Puerto Rican economy that would promote sustainable development. With Plan Chardón, the Puerto Rico Reconstruction Administration was created, which sought to organize economic development (Dietz 1986).

All these economic development policies depict a new dimension of the US colonial state of exception. As Agamben (2005) has shown, during the Great Depression, Roosevelt developed the economic dimension of the state of exception by assuming plenary powers to manage the economic crisis and foster the normalization of the

${ }^{10}$ For a detailed analysis of this period, see Rodríguez (2010). 
economic crisis through exceptional laws. Thus, the extension of these exceptional laws to PR implied the development of an economic and colonial state of exception.

The enforcement of the US colonial state of exception in PR continued in the 40s with the imposition of a new series of exceptional laws that sought development through industrialization, or what was known as "industrialization by invitation" (Ayala and Bernabe 2011, Irizarry 2011). This development policy consisted in legislating tax exemption for US corporations established in PR. This policy favored US corporations and limited the development of local corporations. That is, the capitalist economy in the colonial context of PR was intended to mainly favor US corporations. As a result, PR would see the development of a local middle class, mainly those who worked in these industries, which served as an intermediary for and supporter of US colonial rule. Also, in the 40s, the US developed a military-based economy in PR. Through different legislations and policies, the US established a group of military bases in PR, which simultaneously contributed to land concentration by the US military and to the impoverishment of towns and surrounding areas (Atiles 2014).

The third organic law imposed on PR was the Public Law 600 of 1950. One key element of this organic-exceptional law is that it allowed Puerto Ricans to draft their own constitution and create a local government with a limited degree of autonomy. Thus, the Commonwealth of Puerto Rico (ELA) ${ }^{11}$ was established in 1952. This new local government recognized a certain degree of internal democracy and established a republican system of governance within the antidemocratic structures of the US colonial state of exception. This aspect, however, did not imply a substantial change in PR's political relationship with the US; PR still remained a colony, albeit with certain internal democratic guarantees.

Both the Jones Act (1917) ${ }^{12}$ and the Constitution of the Commonwealth of PR (1952) established that the payment of public debt would have priority over any other payment. As an example, the Constitution of PR provided (Constitution of PR of 1952, art. VI S 8) that when the resources available for a fiscal year are not sufficient to cover the allocations approved for that year, the payment of interest and repayment of public debt shall come in first place, and only then other disbursements can be made in accordance with the order of priorities established by law. All this shows the uses of the colonial state of exception for the establishment of a strict economic structure. That is, given that a great part of bond holders are US citizens living in the US, it is not strange that the economic policy imposed by the US in PR aims to guarantee those interests.

As result of the Oil Crisis of 1973, the economic model of industrialization by invitation entered a recession, which led to a serious economic crisis (Ayala and Bernabe 2011). This crisis caused the closure of an important number of industries on the Island, and also a new transformation in economic development policies. Thus, the 80 s marked a period of stagnation that culminated in a new transition of PR's economic model and the economic and political legal discourses that, for the purposes of this paper, I will call colonial neoliberalism. This transition materialized in the $90 \mathrm{~s}$ with the transformation of the Puerto Rican economy from an industrial extractive-productive economic model to a predominantly postindustrial economic model based on consumption, tourism and the speculative market (Ayala and Bernabe 2011). These transformations were based on two important factors: the elimination of the tax exemption law, known as 936 (PR and possession tax credit, 2012); and the underdevelopment and abandonment of all the previous economic development models, with the exception of pharmaceutical and electronic industries.

\footnotetext{
${ }^{11}$ ELA stands from the Spanish name Estado Libre Asociado de Puerto Rico or Free Associate State.

12 The Jones Act (1917) established, in section 34, the order (based on five classes of instances) in which state funds will be used in case there are not enough funds to run the government. The first class or the priority in the uses of the funds is "the ordinary expenses of the legislative, executive, and judicial departments of the State government, and interest on any public debt, shall first be paid in full".
} 
At the same time that the US'S economic policies imposed on PR were changing, the legal definition of PR was being tested on the US judiciary and political arena as well. Regarding the US judiciary, courts have reacted in different and opposing ways to the creation of the ELA and its constitutional effects. That is, the US judicial branch has reacted in different ways to the legal constitution or legitimation of the colonial state of exception. Therefore, when an analysis of the different legal opinions and rulings is conducted, one can identify at least two positions regarding the creation of the ELA. Firstly, there are the rulings that legitimated the ELA or see the ELA as the expression of local sovereignty. Some examples of such ruling are: Figueroa $v$ People of Puerto Rico (1956) in which the US Court of Appeals for the First Circuit (Boston) ruled that the ELA's constitution was not a mere Congressional Organic Law, such as the Foraker Act and the Jones Act, and established that arguing otherwise was to accuse Congress of fraud. In Hernández Agosto v Romero Barceló (1984) and United States v Quinones (1985), the same Court reiterated the conclusion that the ELA's constitution was not a mere federal statute and, therefore, could not be revoked unilaterally by Congress. In United States v Lopez Andino (1987), the Court of Appeals for the First Circuit concluded once again that the ELA was a separate sovereignty of the USA.

Secondly, there is a group of cases that denies the idea that the ELA involved a transference of sovereignty to PR, and therefore, argues that PR is still a US colony. For example, in in Harris v Rosario (1980), the US Supreme Court determined that, by virtue of its powers under the Territorial Clause, the Congress could treat PR in differently to the rest of the states. In United States v Sánchez (1993), the Court of Appeals for the Eleventh Circuit (Miami) concluded that PR is still a US territory and Congress may unilaterally revoke the Puerto Rican constitution or the Federal Relations Act (Law 600) and replace them with laws or regulations of their choice. Finally, in Puerto Rico v Sánchez Valle (2016) and Puerto Rico v Franklin California (2016), the US Supreme Court concluded that PR has no distinct sovereignty, but continues to be an unincorporated territory, or, a US colony. ${ }^{13}$ Particularly, in Sánchez Valle (2016), the Court decided that PR is not a "sovereign" for the purposes of the double jeopardy clause of the US Constitution, but even if it had decided the opposite, the colonial relationship would not have changed. The policy would have continued to be the same, the US Congress can decide what laws apply and do not apply to PR.

Similarly, to the judiciary, the US executive branch has also reiterated the colonial character of the ELA. For example, the 2007 Report by the President's Task Force on Puerto Rico's Status reinforced the colonial state of exception by highlighting the validity of the colonial condition and the absolute power of Congress over PR. Similarly, another report was produced in 2011, in which it was recognized that PR's status was not solved, and progress should be made in the direction of its resolution. As recently as December 2015, in the context of Puerto Rico v Sánchez Valle (2016), US Attorney General Donald B. Verrilli J r. submitted a brief to the Supreme Court (as amicus curiae), in which he reaffirmed that the US government understood that PR is still a US colony and that ELA did not mean the resolution of status (see Verrilli et al. 2015).

The previous analysis of the opinions issued by various US courts and of the reports drafted by the US government, it can be argued that: (1) the US judicial branch had not developed, until 2016, a clear legal argument of the nature of the ELA; (2) all these decisions demonstrate that the US government uses the law and legal opinion that best suits their interest respecting PR's colonial condition, therefore, both perpetuating and strengthening the ELA and favoring it to be replaced by another type of settlement (statehood, independence, associated republic) are protected opinions issued by the courts; (3) the US government has repeatedly argued that PR remained a colony and that the ELA did not represent the end of PR's colonial condition. Hence, US courts have served the economic and political interests of the

\footnotetext{
${ }^{13}$ For an in-depth analysis of the decision exposed here, see Atiles (2016), and Ayala and Bernabe (2011).
} 
elites who administer the US government and, therefore, it can be affirmed that US colonialism has used the state of exception as a device of colonial administration. This was possible thanks to the mobilization of the three branches of government, the US political-economic elites and the Puerto Rican political elites and parties.

The economic, legal and political history of PR, in a way, proves that the colonial state of exception was key in the economic (under)development of the Island. Moreover, in every historical period above mentioned, the US and the local Puerto Rican government resorted to exceptional laws to promote economic development. Even today, solutions and alternatives to the current economic and financial crisis proposed by colonial neoliberalism consist of legislating new exceptional laws. Hence, the US government, the Puerto Rican government, and the local elites have not aspired to the development of a sustainable political and economic system, but rather their aspirations have been to ensure the exceptionality of the colonial system.

\section{Colonial Neoliberalism and I nternal State of Exception}

Simultaneous to the US's imposition of its colonial state of exception in PR, the local government developed different strategies to promote economic growth and to tackle economic crises. However, these strategies were based on the legal and political framework established by the US. That is, from 1952 onward, the Puerto Rican government and local parties developed a series of policies that in a way contributed to the economic and financial crisis. That is, colonial capitalism was key in the development of the precarious situation in which PR finds itself today. The focus of this section is the analysis of the policies implemented by the local government from 1980 to 2016. The aim of this section is to show how the local government developed, from 1980 onward, an economic internal state of exception. Before exposing the history of the development of the internal state of exception, three important clarifications are necessary. Firstly, in previous work of mine, I have shown how the local government developed the internal state of exception as a dispositive to thwart anticolonial movements, student movements and environmental movements (Atiles $2012,2013,2014$ ). Therefore, in this paper, I am interested in analyzing how the same dispositive implemented to criminalize social and political movements has been implemented to tackle the crisis. Secondly, for the purposes of this paper, I am using the paradigm of the internal state of exception to refer to the state of exception, to the state of emergency and to the fiscal state of emergency. This is precisely what Agamben (2005) does in his analysis of the state of exception as a form-ofgovernment, to maintain consistency.

Thirdly, by studying the development of the internal state of exception through the declaration of executive orders, the suspension of the constitution and the rule of law, and through the legislation of exceptional laws, this paper aims to show that PR is seeing the emergence of a new form of governmentality. This form is still unfolding; therefore, it is still difficult to define clearly. Hence, in this paper, my aim is to point out the emerging issues and the continuities identifiable since the 1980's onwards. In this sense, the internal state of exception is the result of dispositives and techniques of government, neoliberal policies, the economic and financial crisis, and efforts to tackle the crisis while defending ruling classes and colonialist interests.

The last three decades of Puerto Rican history have been characterized by the following aspects: firstly, the local government has intensified the neoliberal policies, such as the reduction of administrative structures, privatization of public services and implementation of austerity measures. Secondly, PR has experienced the development, hegemonization and naturalization of neoliberal ideology. Thirdly, the local executive branch has been taking over more and more power, weakening, in that way, the republican structure on which the local government was built, reducing constitutional and civil rights. This is precisely what Agamben (2005) has described as the practices that have normalized the state of exception in western democracies. Fourthly, as a result of the concentration of power by the executive branch, PR has 
seen the intensification of the authoritarian and antidemocratic discourses and statecorporate criminality endemic of colonial systems.

Rafael Hernández Colon (Popular Democratic Party [PPD] 1985-1993) was one of the first Puerto Rican governors to apply neoliberal discourses and techniques of governmentality as part of his political program. Hernandez's administration incorporated neoliberal policies such as decentralization, privatization, structural adjustment and government downsizing. Also, this administration was the first to incorporate discourses of "there-is-no-alternative". TINA came to symbolize the socialization of economic losses and the privatization of profits under the capitalist assumption that the economy must be above society and public interest. Therefore, society must serve or ensure the smooth functioning of the economy and not viceversa (the economy is not at the service of society).

With the imposition, normalization and naturalization of neoliberalism in PR, from the mid-80s to the present, the progressive destruction of the Puerto Rican colonial welfare state took place. That is, the colonial welfare state was not only destroyed by the US government and its colonial state of exception, but by the Puerto Rican government and its internal state of exception as well. This was the result of the confluence of a young political class, a new global economic scenario and colonial exceptional policies (Bernabe 1998). Thus, from the mid-1980s to the present, the development of colonial neoliberalism materialized (Atiles 2016). These new juridicalpolitical and economic scenarios involved the stagnation of the economy, which was marked by an increase of public debt and by the implementation of problem solving theory. Also, this process was marked by the deregulation that lead to the increase in state-corporate crimes (collusion and corruption) and impunity, and a greater socialization of economic losses produced by speculative economy.

Although initiated by Hernandez's administration, Pedro Roselló's (New Progressive Party [PNP] 1993-2000) administration was responsible for the implementation of neoliberal policies and for their normalization (Ayala and Bernabe 2011). The eight years of Rosselló's administration are characterized by four aspects. Firstly, Rosselló's administration radicalized the processes of privatization and externalization (outsourcing) of public services. Secondly, it developed a strong anti-workers policy that included legislation limiting Unions in the public sector, banning strikes and collective actions, and promoting US-based Unions in PR. Thirdly, Rosselló's administration developed big infrastructure projects that lead to a massive increase of the public debt and were also characterized by high levels of corruptions. Fourthly and finally, it enhanced Puerto Rican mobilizations for statehood. Albeit, these neoliberal policies and mobilizations gave the false impression of growth and economic stability, they increased the Puerto Rican public debt and contributed to the real estate bubble that lead PR to the crisis it is currently undergoing. Rosselló's administration was not alone in imposing neoliberal policies; Sila María Calderón's and Aníbal Acevedo Vilá's administrations (PDP 2000 to 2008) were involved as well and contributed to the incrementation of the public debt.

Governor Acevedo Vilá's administration was the first to incorporate the state of exception as a strategy for economic crisis management. It is important to make a historical distinction, despite the development of neoliberalism in the colonial context, that the previous governments did not develop the internal state of exception as Acevedo Vilá did. In general terms, the emergence of the internal state of exception as policy took place in May 2006, when Acevedo Vilá decreed a partial close of the government, given that the government had no money to pay the employee's payroll. The partial close of the government was decreed through the executive order OE2006-10. This executive order marked the beginning of the usage of the state of exception by the local government to administrate the Puerto Rican economy. As has been shown, the US made systematic use of the colonial state of exception, however, what is new to note is that the local government was using a local state of exception (internal state of exception) not just to control and criminalize anticolonial, student, 
environmental and other social movements, but to regulate and administrate the colonial-economic crisis. The internal state of exception implied the radical reduction of the already antidemocratic Puerto Rican political system and the hyper-legalization of Puerto Rican politics.

In 2009, Luis Fortuño-PNP took office, continuing to implement neoliberal practices and the internal state of exception. It was assumed that to maintain a good credit rating, the state and society had to move to the rhythm of transnational investment and credit-rating agencies, such as Moody's and Standard \& Poor's. Fortuño's administration developed the internal state of exception through two key executive orders. ${ }^{14}$ The first executive order, and perhaps the most important one, was the declaration of the state of fiscal emergency. This declaration was based on the executive orders OE-2009-001 and OE-2009-004 of January 8, 2009, and the legislation of Act 7 of March 9, 2009.

The main arguments for the declaration of the state of fiscal emergency and the enactment of Act 7 were that PR was facing a serious economic and financial crisis that required multiple austerity measures, budgetary cuts and the dismissal of some 20,000 public employees. By the same token, with the enactment of Act 7, the Puerto Rican Legislature legitimated the internal state of exception and its austerity measures. Later, in February 3, 2010, the Puerto Rican Supreme Court ratified the constitutionality of Act 7 and of the declaration of the state of fiscal emergency in the case Olga Domínguez Castro et al. v Puerto Rico et al. (2010). The ruling argued that, given the serious crisis, Act 7 and the state of fiscal emergency constituted reasonable actions to save the solvency of the Puerto Rican treasury.

Thus, in the name of bonds, good credit, fiscal stability, market and local elite interests, Fortuño's administration undertook a violent campaign of austerity with the following effects: (1) the dismissal of 20,000 public employees; (2) the reduction of the budget of the University of Puerto Rico; (3) the privatization of public services; (4) and the development of the strategy for economic growth called Public-Private Partnership. All of these policies and practices were followed by an intense campaign of political violence and the criminalization of social protest.

Fortuño's administration also declared a "state of emergency over energy". The declaration of this state of emergency took effect under executive order OE-2010034. ${ }^{15}$ It established that, since PR depends on the combustion of oil derivatives for $70 \%$ of its electrical energy production (implying a high level of contamination), which has high production costs due to market fluctuations and is also nonrenewable, it is necessary to seek alternative sources of production that cost less, are "environmental friendly" and renewable. To confront this situation, the Administration of Energy Affairs was created, which developed a program to find alternatives to the existing situation.

One can agree with the need to identify alternative energy resources. Nonetheless, the usage of the internal state of exception has several sociopolitical and legal implications that should not escape our attention. It must be noted that a state of exception opens the door to unilateral decision-making that affects the country's future regarding energy, environment and economy; therefore, the effects that such an imposition could directly have on some communities would be rendered invisible. Therefore, the declaration of a state of exception due to energy issues is a new application of the state of exception that allows it to be declared in cases in which the colonial administrative structure is not under threat. Fortuño's administration lost the 2012 elections, paving the way for a new PDP administration under the leadership of Alejandro García Padilla. It is important to note that on December 18, 2012, before Fortuño left office, he promulgated his last executive order: OE-2012-74, which was

\footnotetext{
${ }^{14}$ However, Fortuño promulgated nine other executive orders concerning the economic crisis, which are beyond the scope of this paper.

15 The Spanish version of this law available from: OE-2011-034.
} 
intended to derogate all previous executive orders. The irony of this move is that even though the internal state of exception has been normalized by a long period of time, Fortuño felt the necessity to derogate every executive order that declared the state of exception before the new governor took office.

García's-PDP administration began term under an intense economic and financial crisis, for which he had not developed an adequate economic and financial policy. Hence, his administration applied the same neoliberal and exceptional practices developed over the last decades. An example of this is that, on January 3, 2013, just two days after taking office, García's administration issued the executive order OE2013-03 in order to control the expenditure of public funds, establishing a policy of fiscal control and reduction of administrative expenditure. Subsequently, García's administration issued the executive order OE-2013-14, which allowed PR's Office of Management and Budget to impose a series of measures to control expenditures and fiscal adjustments to ensure that the public administration did not run out of funds. This executive order stated that the administration was committed to promoting the fiscal and economic health of the government through the implementation of austerity measures and the control of expenses while ensuring the rights of public servants to work.

As PR's financial and economic crisis intensified in 2014, credit agencies Moody's, Fitch Rating and Standard \& Poor's reduced the credit ratings of PR's government, its instrumentalities and its public corporations to the lowest possible level. ${ }^{16}$ This reduction brought about the intensification of the neoliberal policies discussed in this paper. Hence, the administration approved a new fiscal stability law (66 of J une 17, 2014), ${ }^{17}$ with which the state of fiscal emergency/exception was officially declared. The preamble of the law indicates that the declaration of the state of fiscal emergency was made to guarantee the fiscal and economic recovery after the degradation of PR's credit and the decrease of tax collections that affected the liquidity of the government. This shows a continuity with the previous administrations regarding the uses of the internal state of exception.

Subsequently, Act 71 of June 28, 2014, entitled Puerto Rico Public Corporation Debt Enforcement and Recovery Act, was passed. The law intended to address the exclusion of the Puerto Rican government and its corporations from Chapter 9 of the federal bankruptcy law (Bankruptcy, 1978). In 1984, the US government, as part of the articulation of the colonial state of exception in the economic sphere, excluded PR and the rest of the unincorporated territories from the applicability of the aforementioned chapter. The exclusion of PR leaves it in a legal vacuum that does not allow it to restructure its public debt. Consequently, the government of PR attempted to address this exclusion from the federal bankruptcy law by legislating a local bankruptcy law.

In addition to the declaration of the state of fiscal emergency, and the approval of the local bankruptcy law, García's administration and PR's Legislature, with the intention of solving the economic and financial crisis, passed the following laws: a reform of public employee retirement; the imposition of two special taxes on oil; budget cuts to all public agencies; the approval of sales taxes; and, finally, the privatization of public infrastructures and corporations, such as airports and highways, through the model of public-private alliances.

In 2015, PR's government hired Dr. Anne O. Krueger (former director of the International Monetary Fund (IMF)) to conduct an analysis of the Puerto Rican crisis. The resulting report (the Krueger Report; see Krueger et al. 2015) had two important effects: it backed up the neoliberal austerity measures taken by García's administration, and it asserted that PR's public debt was unsustainable and

${ }^{16}$ For an analysis, see: Gobierno de Puerto Rico 2014.

17 Special Law of Fiscal and Operational Sustainability of the Government of the Commonwealth of Puerto Rico. 
unpayable. Hence, the report's recommendation was to restructure and renegotiate the debt. In addition, the report emphasizes that solutions to the crisis cannot only focus on structural adjustments, but on the implementation of new economic development policies as well.

Later, the government issued the executive order OE-2015-022, which intended to implement some of the Krueger Report's recommendations. Also, the Working Group for Fiscal and Economic Recovery of Puerto Rico was created. ${ }^{18}$ This working group was assigned the drafting of a fiscal and economic adjustment plan that should contain a series of recommendations to tackle the economic and financial crisis. The plan was published on September 9, 2015, ratifying the neoliberal exceptional policies that the administration had been developing over the past two years. ${ }^{19}$

Continuing with exceptional policies, on April 6, 2016, the Puerto Rican Legislature passed Act 21 of 2016, known as the Puerto Rico Emergency Moratorium and Financial Rehabilitation Act (see Ley núm. 21, 6 abril 2016). With this Act, once again, the Legislature gave the governor the power to declare the non-payment of the Puerto Rican public debt. In this way, the last legislation of the internal state of exception in PR under Garcia's administration was approved. In short, this law provided the governor with the necessary tools for the normalization of the internal state of exception. This law also created the Financial Advisory Authority and Fiscal Agency of PR, which was structured as a public corporation of PR's government. That is, an agency was created to articulate the exceptional policies issued by the executive branch, and with this, PR's Legislature renounced its constitutional power to be a counterbalance to the executive power. As Agamben (2005) has shown, this is an example of how the state of exception operates.

Finally, the approval of Act 21 gave way to the declaration of seven executive orders in 2016. That is, all executive orders related to the economic and financial crisis, issued in 2016, were declared under the protection of this law (see OE-2016-10, OE2016-14, OE-2014-17, OE-2016-26, OE-2016-27, OE-2016-30, OE-2016-31). This is fundamental for the understanding of the argument hitherto presented, since these executive orders declared the state of fiscal emergency. Hence, it can be argued that all government public policies regarding the economic and financial crisis in 2016 were based on the usage of the internal state of exception. In short, Garcia's administration has definitively normalized the use of exceptionality.

\section{The I nternal State of Exception and the Reaffirmation of US Colonial State of Exception}

The years 2016 and 2017 are the kind of years that will mark PR's colonial history. Firstly, throughout both years, PR has seen the intensification of the economic and financial crisis that has been affecting PR since 2006, and with it, the radicalization of neoliberal austerity measures. Secondly, along with the austerity measures and/or political violence of colonial neoliberalism, Puerto Ricans have seen the juridicalpolitical reaffirmation of US colonialism in PR.

Regarding the reaffirmation of US colonialism in PR, all three branches of the US government exercised their colonial power over the Island. For example, the US Congress legislated, and President Obama signed the Public Law No. 114-118, known as PROMESA (S. 2328, 114th Congress (2015-2016). This law is the colonial state of exception and neoliberal solution proposed by the US government to address PR's economic and financial crisis. That is, for the first time since the Puerto Rican economic crisis began, the US colonial government took action to solve it. The interesting thing is that PROMESA does not recognize the effects of colonialism on

\footnotetext{
18 The creation of the working group was later legislated through Act 208 of December 8, 2015, also known as Puerto Rico Fiscal Oversight and Economic Recovery Organic Act.

19 Report entitled: Puerto Rico Fiscal and Economic Growth Plan (Working Group for the Fiscal and Economic Recovery of Puerto Rico 2015).
} 
the Puerto Rican economy, and it is accompanied by the imposition of a Financial Oversight Board, or a body that regulates the budget and funds of PR's government. The Board is a colonial body in charge of ensuring the survival of the capitalist and financial system imposed in PR since 1970, as well as guaranteeing the payment of the public debt and getting PR back to financial and stock markets. An important aspect of the Board is that it was given powers that could be used to suspend the effects of certain laws. That is, laws that are inconsistent with the Board's fiscal plan, showing a reaffirmation of the colonial state of exception.

The second aspect that proves the reaffirmation of US colonialism in PR is the decisions issued by the US Supreme Court in Puerto Rico v Sánchez Valle (2016) and in Puerto Rico v Franklin California (2016). The case of Puerto Rico V Franklin California (2016) is key to understand the colonial state of exception. In this case, it was argued that PR could not legislate a bankruptcy law, since, despite the fact that PR was excluded from Chapter 9 of the federal bankruptcy law in 1984, the country remained a "state" for the purposes of this law. In short, the US Supreme Court concluded in Puerto Rico v Sánchez Valle (2016) that PR has no sovereignty since it is not a state of the Union, but at the same time, Puerto Rico v Franklin California (2016) concluded that PR is a state for the effects of federal bankruptcy laws, hence, it is excluded from the applicability of the law. These decisions showed that, under Schmittian logic, the Sovereign decides on the applicability of the law and on the exception. Thus, the US showed that the internal state of exception should be limited to the scope defined by the colonial state of exception. That is, the anomie constituted by the internal state of exception (in this case the legislation of an exceptional law that aims to allow PR's public corporation to declare bankruptcy was overruled by the Supreme Court) can only operate within the space constituted by US colonial sovereignty.

Despite the reaffirmation of colonialism and its legal dimension, as well as the delegitimation of the internal state of exception, PR's government continued to implement exceptional policies to address the economic and financial crisis. In this sense, one of the parties most affected by the economic crisis was the PPD and the then-governor García, who could not even run for the 2016 elections. Ricardo Rosselló Nevares (son of colonial neoliberalist boy scout, Pedro Rosselló) and the PNP won the 2016 elections.

Rosselló-PNP continued with the neoliberal austerity measures and with the internal state of exception. For example, in his first days in office, on January 2, 2017, Rosselló issued six executive orders aimed at managing the economic crisis. In this way, Rosselló became part of the tradition of administering PR's economy through the internal state of exception. Specifically, executive order OE-001-2017 declared a state of fiscal emergency and introduced a new set of exceptional measures to be applied in the name of saving economic and financial interests. This executive order, as well as those subsequently signed, radicalized the internal state of exception and the political violence of austerity.

At the same time, the legislative branch approved Act 5 on January 29, 2017, in which the Financial Emergency and Fiscal Responsibility of Puerto Rico Act was passed. This new law made a legislative declaration of the state of fiscal emergency, legitimating the exceptional measures taken by Rosselló during his first month in office. In addition, Rosselló's administration created new and transformed departments to serve economic and financial interests. This is the case of the Puerto Rico Fiscal Agency Financial Advisory Authority (AAFAF) [see Ley núm. 2 de 18 de enero de 2017). This agency is in charge of developing and implementing the fiscal plan and the austerity measures that would guarantee the payment of the public debt of PR. Also, AAFAF is in charge of being the intermediary with the Control Board.

Simultaneously, Rosselló eliminated the Puerto Rico Commission for Comprehensive Audit of Public Credit (2016), previously created by García's administration. With the elimination of the Commission, Rosselló's administration showed his connivance 
regarding financial, economic and political interests that led PR to its current crisis. Thus, the role of the previous colonial administrations, the role of Banks, and the corrupt practices that led PR to its current crisis were actively disguised by Rosselló's administration. Hence, it can be argued that the internal state of exception have been used by PR's government to protect corporate and financial interests that led PR to its current situation, especially to guarantee corporate welfare and to criminalize and demobilize political practices.

Later on, hurricanes Irma and Maria struck PR, generating a new stage of the uses of the internal state of exception, in this case, in relation to natural disasters. During the aftermath of hurricane Maria, PR has been living a humanitarian crisis, which has created the conditions for the exacerbation of the double exceptionality, economic crisis, and disaster capitalism. This new reality and the normalization of the internal state of exception entail a new development with regards to the uses of exceptionality as a form-of-government. ${ }^{20}$

\section{Conclusion}

Colonial state of exception, exceptional laws and the application of the internal state of emergency, have proved ineffective in dealing with the economic and financial crisis affecting PR. On the contrary, what we have noticed up to this point is that these strategies have intensified the effects of the crisis, particularly affecting the poorest and most disadvantaged sectors of the country. In short, it can be argued that exceptionality, and the precariousness its produces, would not have been possible without the colonial state of exception under which US domination operates in PR.

The internal state of exception implied the effective conjunction between neoliberalism, juridical-political discourses of security and the use of the law to legitimize the extra-legal and antidemocratic actions of PR's government. As has been pointed out, since the 2000s, PR's government imposed various exceptional legislations that unsuccessfully sought to address the economic and financial crisis. These exercises of exceptionality took place within the US colonial state of exception and had the acquiescence of the US government. While it is true that the US government did not actively participate in local administration since 1952, it did maintain its colonial control and domination. An example of this is that, since 1900, all US laws and regulations, with some exceptions, apply in PR as they do in all states. In addition, it is important to acknowledge that none of those US laws and regulations have been suspended as a result of the crisis. ${ }^{21}$ At the same time, the double exceptionality (colonial and internal), combined in recent years, helps to maintain constant pressure on the local economy and to guarantee the interests of the local and US economic elites. Proof of this is the most recent reaffirmations of US colonial domination.

All of this evidences that the usage of the state of exception, and the conjunction between neoliberal policies and the reduction of the scope of political action, has become the norm. This new depoliticized administration paradigm has become the epitome of hyper-juridification and the depoliticization of Puerto Rican public life. Thus, all political alternatives to colonialism and to the economic and financial crisis have been based on legal, not political, criteria. Hence, Puerto Rican politics and local administration have been transformed into techniques of economic administration. This has led to the abandonment of Puerto Ricans to colonial law, and with it, to the inoperability of Politics.

\footnotetext{
${ }^{20}$ As stated earlier, the analysis conducted in this paper covers up until the first month of Rosselló's administration. A further development of the uses of the internal state of exception under Rosselló's administration will be published in Atiles (Forthcoming 2018).

${ }^{21}$ This was the case of the Cabotage Laws in the aftermath of Hurricane Maria. These laws were suspended for a period of ten days, and were quickly reinstated, despite the precarious conditions that Puerto Ricans were living under after the hurricane. For more details, see Ruiz Kulian 2017.
} 


\section{References}

Agamben, G., 1998. Homo Sacer: El poder y la nuda vida. Trans.: A. Gimeno. Valencia: Pre-Textos.

Agamben, G., 2005. State of Exception (Homo Sacer II, 1). University of Chicago Press.

Agamben, G., 2008. El Reino y la gloria: Por una genealogía teológica de la economía y del gobierno (Homo Sacer II, 2). Trans.: A. Gimeno. Valencia: Pre-Textos.

Atiles, J., 2012. The Criminalisation of Anti-Colonial Struggle in Puerto Rico. In: S. Poynting and D. Whyte, eds., Counter-terrorism and State Political Violence: The 'War on Terror' as Terror. London: Routledge, 156-177.

Atiles, J., 2013. Neoliberalism, Law and Strike: Law as Instrument of Repression in the Student Strikes at the University of Puerto Rico between 2010 and 2011. Latin American Perspectives, 40 (5), 105-117.

Atiles, J., 2014. Environmental Colonialism, Criminalization and Resistance: Puerto Rican movements for environmental justice in the $21^{\text {st }}$ century. RCCS Annual Review, 6 (6), 3-21.

Atiles, J., 2016. Apuntes para abandonar el derecho: Estado de excepción Colonial en Puerto Rico. Cabo Rojo: Educación Emergente.

Atiles, J., forthcoming 2018. Internal State of Exception and the Puerto Rican Economic and Financial Crisis. Caribbean Voices.

Ayala, C., and Bernabe, R., 2011. Puerto Rico en el siglo americano: su historia desde 1898. San Juan: Callejón.

Bernabe, R., 1998. Puerto Rico's La Huelga del Pueblo. Solidarity [online], September-October. Available from: http://www.solidarityus.org/site/node/1796 [Accessed 23 May 2018].

Brown, W., 2015. Undoing the Demos: Neoliberalism's Stealth Revolution. New York: Zone Books.

Burnett, C., 2005. United States: American Expansion and Territorial Deannexation. The University of Chicago Law Review, 72 (3), 797-879.

Butler, J., 2004. Precarious Life: The Powers of Mourning and Violence. London: Verso.

Cintrón Aguilú, A., 2014. The 500 Acres Law. Enciclopedia de Puerto Rico [online], 15 September. Available from: https://enciclopediapr.org/en/encyclopedia/the-500-acres-law/ [Accessed 23 May 2018].

Cooper, V., and Whyte, D., eds., 2017. The Violence of Austerity. London: Pluto Press.

Dietz, J., 1986. Economic History of Puerto Rico: Institutional Change and Capitalist Development. Princeton University Press.

Estades, M. E., 1999. La presencia militar de Estados Unidos en Puerto Rico 18981918. Intereses estratégicos y dominación colonial. Río Piedras: Huracán.

Eyermann, C., 2016. Puerto Rico Officially Defaults on Its Debt. MyGovCost.org [online], 2 May. Available from:

http://www. mygovcost. org/2016/05/02/puerto-rico-officially-defaults-on-itsdebt/ [Accessed 22 May 2018].

Gobierno de Puerto Rico, 2014. Agenda para la recuperación económica 2014-2018 [online]. Estado Libre Asociado de Puerto Rico. Available from: 
http://www2.pr.gov/presupuestos/Presupuesto2014-

2015/Informacin\% 20de\% 20Referencia/Plan\% 20para\% 20la\% 20Recuperaci\% C 3\%B3n\%20Econ\% C3\% B3mica\% 202014-2018.pdf [Accessed 23 May 2018].

Irizarry, E., 2011. Economía de Puerto Rico. Ciudad de México: McGraw-Hill.

Jimenez, M., forthcoming 2018. Puerto Rico under the Colonial Gaze: Oppression, Resistance and the Myth of the Nationalist Enemy. Latino Studies.

J offe, M., 2016. Puerto Rico's Fiscal Crisis Has Been Brewing for 75 Years. The Fiscal Times [online], 15 March. Available from:

http://www. thefiscaltimes.com/2016/03/15/Puerto-Rico-s-Fiscal-Crisis-HasBeen-Brewing-75-Years?amp [Accessed 22 May 2018].

Kaske, M., 2018. Greek Tragedy Redux? Puerto Rico Embraces Risky Austerity Plan. Bloomberg Quint [online], 15 March, updated 20 March. Available from: https://www. bloombergquint.com/markets/2018/03/15/greek-tragedy-reduxpuerto-rico-embraces-risky-austerity-plan [Accessed 22 May 2018].

Krueger, A.O., Teja, R., and Wolfe, A., 2015. Puerto Rico - A Way Forward. Executive Summary [also known as Krueger Report] (online). Commonwealth of Puerto Rico, 29 June. Available from: http://www.gdb.pr.gov/documents/puertoricoawayforward.pdf [Accessed 23 May 2018].

López Baralt, J., 1999. The Policy of the United States towards its Territories with Special Reference to Puerto Rico. San Juan: Universidad de Puerto Rico.

Marans, D., 2016. Puerto Rico Is In Serious Trouble. Here's What You Need To Know. The Huffington Post [online], 2 January, updated 5 J anuary. Available from: http://www. huffingtonpost.com/entry/puerto-rico-debt-defaultexplained_us_56870c25e4b0b958f65bca7a [Accessed 22 May 2018].

Mbembe, A., 2003. Necropolitics. Public Culture [online], 15 (1), 11-40. Available from: https://doi.org/10.1215/08992363-15-1-11 [Accessed 23 May 2018].

Morton, S., 2013. States of Emergency: Colonialism, Literature and Law. Liverpool University Press.

Ong, A., 2006. Neoliberalism as Exception: Mutations in Citizenship and Sovereignty. Durham, NC / London: Duke University Press.

Puerto Rico Commission for the Comprehensive Audit of the Public Credit, 2016. Second Interim Pre-Audit Survey [online]. Available from: http://sptpr. net/wp-content/uploads/2016/10/Second-Interim-Pre-AuditReport-on-2013-PREPA-debt-emission-con-anejos.pdf [Accessed 23 May 2018].

Reynolds, J., 2012. The Political Economy of State of Emergency. Oregon Review of International Law, 14, 85-130.

Rivera Ramos, E., 2001. The Legal Construction of Identity: The Judicial and Social Legacy or American Colonialism in Puerto Rico. Washington, DC: American Psychological Association.

Rodríguez, M., 2010. A New Deal for the Tropics: Puerto Rico during the Depression Era, 1932-1935. Princeton: Markus Wiener.

Rosenfeld, E., 2015. Puerto Rico could become "humanitarian crisis": Treasury Counselor. CNBC [online], 22 October. Available from: http://www.cnbc.com/2015/10/22/puerto-rico-could-become-humanitariancrisis-treasury-counselor.html [Accessed 22 May 2018].

Ruiz Kulian, G., 2017. Exención a las normas de cabotaje no tuvo el efecto esperado. El nuevo día [online], 10 October. Available from: 
https://www.elnuevodia.com/negocios/economia/nota/exencionalasnormasde cabotajenotuvoelefectoesperado-2364823/ [Accessed 23 May 2018].

Salmon, F., 2015. The tragedy of Puerto Rico, America's very own Greece. Splinter [online], 30 J une. Available from: https://splinternews.com/the-tragedy-ofpuerto-rico-americas-very-own-greece-1793848804 [Accessed 22 May 2018].

Schmitt, C., 2005. Political Theology. University of Chicago Press.

Schmitt, C., 2006. The Nomos of the Earth: In the International Law of the Jus Publicum Europaeum. New York: Telos Press.

The Economist, 2013. Puerto Rico. Greece in the Caribbean. The Economist [online], 26 October. Available from:

http://www.economist.com/news/leaders/21588374-stuck-real-debt-crisis-itsback-yard-america-can-learn-europes-aegean [Accessed 22 May 2018].

Venator Santiago, C., 2006. From the Insular Cases to Camp X-Ray: Agamben's State of Exception and United States Territorial Law. In: A. Sarat, ed., Studies in Law, Politics and Society, vol. 39, 15-55.

Verrilli, D.B., et al., 2015. Brief for the United States as Amicus Curiae Supporting Responders, in the case of Commonwealth of 'Puerto Rico v. Sánchez Valle et al.' [online]. Available from: http://www.scotusblog.com/wpcontent/uploads/2015/12/US-amicus-brief-in-Valle-15-108. pdf [Accessed 23 May 2018].

Whyte, D., 2010. The Neo-liberal State of Exception in Occupied Iraq. In: W. Chambliss, R. Michalowski and R. Kramer, eds., State Crime in the Global Age. London: Willan, 134-151.

Working Group for the Fiscal and Economic Recovery of Puerto Rico, 2015. Puerto Rico Fiscal and Economic Growth Plan [online]. Report. 9 September. Available from:

http://www.gdb.pr.gov/documents/PuertoRicoFiscalandEconomicGrowthPlan9. 9.15.pdf [Accessed 23 May 2018].

\section{Legal sources}

Act 208 of 8 December 2015. Puerto Rico Fiscal Oversight and Economic Recovery Organic Act [online]. Available from:

http://www.gdb.pr.gov/investors_resources/documents/A-208-2015.pdf [Accessed 23 May 2018].

Act 66 of 17 June 2014. An Act to Create the Government of the Commonwealth of Puerto Rico Special Fiscal and Operational Sustainability Act [online]. Available from: http://www.oslpr.org/download/en/2014/A-066-2014.pdf [Accessed 23 May 2018].

Act 71 of 28 J une 2014. Puerto Rico Public Corporation Debt Enforcement and Recovery Act [online]. Available from:

http://www. lexjuris.com/lexlex/Leyes2014/lex/2014071d.htm [Accessed 23 May 2018].

Act of 2 March 1917. An Act To provide a civil government for Porto Rico, and for other purposes [known as J ones Act of Puerto Rico]. 64th Cong., S. 39, 2nd sess., ch. 145 [online]. Available from:

http://www. legisworks.org/congress/64/publaw-368.pdf

Act of 3 July 1950. An Act to provide for the organization of a constitutional government by the people of Puerto Rico [known as Puerto Rico Federal Relations Act]. 81st Cong., 2nd Sess., ch. 446 [online]. Available from: https://www.loc.gov/law/help/statutes-at-large/81st-congress/session2/c81s2ch446.pdf [Accessed 23 May 2018]. 
Bankruptcy. 11 U.S. Code (1978).

Constitution of the Commonwealth of Puerto Rico [online]. 5 February 1952. Available from: http://www. constitution.org/cons/puertorico-eng.htm [Accessed 23 May 2018].

Ley núm. 2 de 18 de enero de 2017. Para crear la Autoridad de Asesoría Financiera y Agencia Fiscal de Puerto Rico (AAFAF) [online]. Available from: http://www. lexjuris.com/lexlex/Leyes2017/lexl2017002.pdf [Accessed 23 May 2018].

Ley núm. 21 de 6 de abril de 2016. Para crear la Ley de Moratoria de emergencia y Rehabilitación Financiera de Puerto Rico [online]. Available from: http://www.gdb.pr.gov/spa/documents/ley-21-06-Abr-2016.pdf [Accessed 23 May 2018].

OE-2009-001. Orden ejecutiva del gobernador del Estado Libre Asociado de Puerto Rico para decretar un estado de emergencia fiscal e implantar medidas iniciales de control fiscal y reconstrucción económica [online]. Available from: http://app.estado.gobierno.pr/Ordenes_Ejecutivas/2009/OE-2009-1.pdf [Accessed 23 May 2018].

OE-2009-004. Orden ejecutiva del gobernador del Estado Libre Asociado de Puerto Rico estableciendo medidas adicionales de austeridad, disciplina y reducción de gastos [online]. Available from: http://app.estado.gobierno.pr/Ordenes_Ejecutivas/2009/OE-2009-4.pdf [Accessed 23 May 2018].

OE-2010-034. Orden Ejecutiva del gobernador de Puerto Rico para activar las disposiciones de la Ley número 76 de 5 de mayo de 2000 [online]. Available from: http://app.estado.gobierno.pr/Ordenes_Ejecutivas/2010/OE-2010034.pdf [Accessed 23 May 2018].

OE-2011-034. Orden Ejecutiva del gobernador interino de Puerto Rico para enmendar el procedimiento de aprobación de contratos de servicios [online]. Available from: http://app.estado.gobierno.pr/Ordenes_Ejecutivas/2011/OE2011-034.pdf [Accessed 23 May 2018].

OE-2012-074. Orden Ejecutiva del Gobernador de Puerto Rico para derogar las Órdenes Ejecutivas OE-2009-1, OE-2009-2, OE-2009-4, OE-2009-034, OE2009-35, OE-2010-30, OE-2011-27, OE-2011-34 y OE-2012-3 [online]. Available from: https://estado.pr.gov/apex/apex_util.get_blob?s $=30170158727897 \& a=118 \& \mathrm{C}$ $=8707128265807757 \& p=15 \& \mathrm{k} 1=287 \& \mathrm{k} 2=\& \mathrm{ck}=\mathrm{BA524AE63227C92D391 \textrm {F } 4 \mathrm { CD }}$ D662630CF\&rt=IR [Accessed 23 May 2018].

OE-2013-014. Orden Ejecutiva del Gobernador del Estado Libre Asociado de Puerto Rico, Hon. Alejandro J. García Padilla, para delegar al Director de la Oficina de Gerencia y Presupuesto los poderes establecidos en el Artículo 4(e) de la Ley Núm. 147 del 18 de junio de 1980, según enmendada, e implantar medidas de control fiscal [online]. Available from:

https://estado.pr.gov/apex/apex_util.get_blob?s $=30170158727897 \& a=118 \& \mathrm{c}$ $=8707128265807757 \& \mathrm{p}=15 \& \mathrm{k} 1=147 \& \mathrm{k} 2=\& \mathrm{ck}=\mathrm{ECCC} 27 \mathrm{DFD} 01 \mathrm{~A} 239959906 \mathrm{D} 3$ 959557A2F\&rt=IR [Accessed 23 May 2018].

OE-2013-03. Orden Ejecutiva del Gobernador del Estado Libre Asociado de Puerto Rico, Hon. Alejandro J. García Padilla, para implementar medidas adicionales de control en el gasto de fondos públicos en relación con el uso de vehículos de motor oficiales, uso de escoltas, uso de celulares y asistentes digitales personales, uso de tarjetas de crédito y realización de viajes oficiales [online]. Available from: https://estado.pr.gov/apex/apex_util.get_blob?s=30170158727897\&a=118\&c 
$=8707128265807757 \& p=15 \& k 1=136 \& k 2=\& c k=D 2 A 8 A 0 B 46 F 03 A 9966423705$

30252DD97\&rt=IR [Accessed 23 May 2018].

OE-2014-17. Orden Ejecutiva del Gobernador Interino del Estado Libre Asociado de Puerto Rico, Hon. Víctor A. Suárez Meléndez, al amparo del Artículo 103 de la Ley 21-2016, conocida como la "Ley de Moratoria de Emergencia y

Rehabilitación Financiera de Puerto Rico", para excluir ciertas obligaciones de la Autoridad de Energía Eléctrica de Puerto Rico de la aplicación de dicha Ley [online]. Available from:

https://estado.pr.gov/apex/apex_util.get_blob?s $=30170158727897 \& a=118 \& \mathrm{c}$ $=8707128265807757 \& p=15 \& \mathrm{k} 1=2141 \& \mathrm{k} 2=\& \mathrm{ck}=8 \mathrm{~B} 66 \mathrm{~B} 564 \mathrm{D} 27 \mathrm{EC} 9776500 \mathrm{C} 9$

C2B3B98D50\&rt=IR [Accessed 23 May 2018].

OE-2015-022. Orden Ejecutiva del gobernador del Estado Libre Asociado de Puerto rico, Hon. Alejandro García Padilla, para crear el grupo de trabajo para la recuperación fiscal y económica de Puerto Rico y asignarle responsabilidades y facultades [online]. Available from:

http://www.gdb.pr.gov/spa/documents/OE-2015-022.pdf [Accessed 23 May 2018].

OE-2016-10. Orden Ejecutiva del Gobernador del Estado Libre Asociado de Puerto Rico, Hon. Alejandro J. García Padilla, al amparo de los Artículos 201 y 203 de la Ley Núm. 21-2016, conocida como la "Ley de Moratoria de Emergencia y Rehabilitación Financiera de Puerto Rico", para declarar un período de emergencia para el Banco Gubernamental de Fomento para Puerto Rico, atender el desembolso de depósitos y préstamos por dicho Banco y ordenar la implementación de otras medidas razonables y necesarias para permitir a dicho Banco continuar llevando a cabo sus operaciones [online]. Available from:

https://estado.pr.gov/apex/apex_util.get_blob?s $=30170158727897 \& a=118 \& \mathrm{c}$ $=8707128265807757 \& p=15 \& \mathrm{k} 1=2043 \& \mathrm{k} 2=\& \mathrm{ck}=3204822 \mathrm{CA} 4 \mathrm{~B} 28 \mathrm{DC} 88 \mathrm{~B} 9 \mathrm{C} 1 \mathrm{~B}$ 52E891EFE1\&rt=IR [Accessed 23 May 2018].

OE-2016-14. Orden Ejecutiva del Gobernador del Estado Libre Asociado de Puerto Rico, Hon. Alejandro J. García Padilla, al amparo de los Artículos 201, 202 y 203 de la Ley Núm. 21-2016, conocida como la "Ley de Moratoria de Emergencia y Rehabilitación Financiera de Puerto Rico", para declarar una moratoria en el pago de ciertas obligaciones del Banco Gubernamental de Fomento para Puerto Rico, declarar un periodo de emergencia para la Autoridad para el Financiamiento de la Infraestrucutra de Puerto Rico, para ordenar la implantación de otras medidas que son razonables y necesarias para permitir que se continúen brindando servicios esenciales para proteger la salud, seguridad y el bienestar de los residentes del Estado Libre Asociado de Puerto Rico, y para enmendar el decimoquinto de los Por Tanto del Boletín Administrativo Núm.: OE-2016-10 [online]. Available from: https://estado.pr.gov/apex/apex util.get blob?s $=30170158727897 \& a=118 \& \mathrm{c}$ $=8707128265807757 \& p=15 \& \mathrm{k} 1=2101 \& \mathrm{k} 2=\& \mathrm{ck}=\mathrm{CA} 2 \mathrm{D} 0 \mathrm{AE} 873773 \mathrm{D} 6 \mathrm{E} 0 \mathrm{~F} 3 \mathrm{AAF}$ 33E13B6803\&rt=IR [Accessed 23 May 2018].

OE-2016-26. Orden Ejecutiva del Gobernador Interino del Estado Libre Asociado de Puerto Rico, Hon. Rafael Román Meléndez, al amparo del Artículo 103 de la Ley 21-2016, conocida como la "Ley de Moratoria de Emergencia y Rehabilitación Financiera de Puerto Rico", para excluir ciertas obligaciones de la Autoridad de Energía Eléctrica de Puerto Rico de la aplicación de dicha Ley [online]. Available from:

https://estado.pr.gov/apex/apex_util.get_blob?s $=30170158727897 \& a=118 \& \mathrm{C}$ $=8707128265807757 \& \mathrm{p}=15 \& \mathrm{k} 1=2241 \& \mathrm{k} 2=\& \mathrm{ck}=7 \mathrm{~B} 386757552702 \mathrm{E} 638951 \mathrm{~B}$ 27F3F9212F\&rt=IR [Accessed 23 May 2018]. 
OE-2016-27. Orden Ejecutiva del Gobernador del Estado Libre Asociado de Puerto Rico, Hon. Alejandro J. García Padilla, al amparo de la Ley Núm. 21 -2016, según enmendada, conocida como la "Ley de Moratoria de Emergencia y Rehabilitación Financiera de Puerto Rico", para ordenar la implementación de medidas con relación a la Autoridad para el Financiamiento de la Infraestructura del Estado Libre Asociado de Puerto Rico que son razonables y necesarias para la continuación de la prestación de los servicios esenciales para proteger la salud, la Seguridad, la educación y el bienestar de los residents en el Estado Libre Asociado de Puerto Rico [online]. Available from: https://estado.pr.gov/apex/apex_util.get_blob?s $=30170158727897 \& a=118 \& \mathrm{C}$ $=8707128265807757 \& p=15 \& \mathrm{k} 1=2281 \& \mathrm{k} 2=\& \mathrm{ck}=63 \mathrm{FF} 8 \mathrm{~F} 17 \mathrm{D} 1 \mathrm{CEA69BFA7D} 42$ F7DEC75C55\&rt=IR [Accessed 23 May 2018].

OE-2016-30. Orden Ejecutiva del Gobernador del Estado Libre Asociado de Puerto Rico, Hon. Alejandro J. García Padilla, al amparo de los Artículos 201 y 202 de la Ley Núm. 21-2016, según enmendada, conocida como "Ley de Moratoria de Emergencia y Rehabilitación Financiera de Puerto Rico", para declarar un periodo de emergencia para el Estado Libre Asociado de Puerto Rico (el "ELA"), y ordenar la implementación de otras medidas razonables y necesarias para la continuación de la prestación de los servicios esenciales para proteger la salud, la seguridad y el bienestar de los residentes en el Estado Libre Asociado de Puerto Rico; y para otros fines relacionados [online]. Available from:

https://estado.pr.gov/apex/apex_util.get_blob?s $=30170158727897 \& a=118 \& \mathrm{C}$ $=8707128265807757 \& \mathrm{p}=15 \& \mathrm{k} 1=2284 \& \mathrm{k} 2=\& \mathrm{ck}=8 \mathrm{DDCE} 8 \mathrm{~F} 89393 \mathrm{E} 8 \mathrm{BB} 68 \mathrm{~F} 28 \mathrm{~A}$ FE75EFB4BF\&rt=IR [Accessed 23 May 2018].

OE-2016-31. Orden Ejecutiva del Gobernador del Estado Libre Asociado de Puerto Rico, Hon. Alejandro J. García Padilla, al amparo de la Ley Núm. 21-2016, según enmendada, conocida como "Ley de Moratoria de Emergencia y Rehabilitación Financiera de Puerto Rico", para declarar un periodo de emergencia para ciertas entidades gubernamentales, aplazar ciertas obligaciones de deuda de esas entidades, suspender transferencias de ingresos y ordenar la implementación de otras medidas razonables y necesarias para ala continuación de la prestación de los servicios esenciales para proteger la salud, la seguridad y el bienestar de los residentes en el Estado Libre Asociado de Puerto Rico [online]. Available from: https://estado.pr.gov/apex/apex_util.get_blob?s $=30170158727897 \& a=118 \& \mathrm{c}$ $=8707128265807757 \& p=15 \& \mathrm{k} 1=2285 \& \mathrm{k} 2=\& \mathrm{ck}=0361 \mathrm{~B} 5 \mathrm{EFDD} 939 \mathrm{~A} 948948 \mathrm{~B} 8$ 81413E54CF\&rt=IR [Accessed 23 May 2018].

Organic Act of April 12, 1900. An Act temporarily to provide revenues and a civil government for Puerto Rico, and for other purposes [known as Foraker Act]. 56th Congress, 1st Session, chapter 191, stat. 77 [online]. Available from: http://www. legisworks.org/congress/56/session-1/chap-191.pdf [Accessed 23 May 2018].

Puerto Rico and possession tax credit. 26 U.S. Code § 936 (2012).

S. 2328 - PROMESA. 114th Congress (2015-2016) [online]. Available from: https://www.congress.gov/bill/114th-congress/senate-bill/2328 [Accessed 22 May 2018].

\section{Case law}

Figueroa v the People of Puerto Rico, 232 R.2d 615 (1st Cir. 1956).

Financial Oversight and Management Board for Puerto Rico, 17-cv-01578.

Commonwealth of Puerto Rico (17-03283) (U.S. Bankruptcy Ct. for DPR).

Harris v Rosario, 446 U.S. 651 (1980). 
Hernández Agosto v Romero Barceló, 748 F.2d 1 (1st Cir.1984).

Negron Matos v E.L.A. y otros, 2010 TSPR 86.

Olga Domínguez Castro et al v. Puerto Rico et al. 178 D.P.R. 1, 2010 TSPR 11.

Puerto Rico v Franklin California Tax-Free Trust (U.S. Sup. Ct. J une 13, 2016)

United States v López Andino, 831 F2d 1164 (1st Cir. 1987).

United States v Quiñones, 758 F.2d 40 (1st Cir. 1985).

United States v Sánchez, 992 F.2d 1143 (11th Cir. 1993). 